\title{
Bacteriocin-Like Substances from Tomato Race 3 Strains of Xanthomonas campestris pv. vesicatoria
}

\author{
S. M. Tudor-Nelson, G. V. Minsavage, R. E. Stall, and J. B. Jones
}

Department of Plant Pathology, University of Florida, Gainesville 32611.

Accepted for publication 1 July 2003.

\begin{abstract}
Tudor-Nelson, S. M., Minsavage, G. V., Stall, R. E., and Jones, J. B. 2003. Bacteriocin-like substances from tomato race 3 strains of Xanthomonas campestris pv. vesicatoria. Phytopathology 93:1415-1421.

Tomato race 3 (T3) strains of Xanthomonas campestris pv. vesicatoria are antagonistic in vitro to tomato race 1 (T1) strains of the bacterium. All T1 strains and 11 strains of other $X$. campestris pathovars tested were inhibited by T3 strains. Sensitivity of tomato race 2 (T2) strains was variable. No strains from other bacterial genera tested were inhibited. Cell-free filtrates from T3 strains were inhibitory to sensitive strains. The inhibitory activity of these filtrates was lost after treatment at temperatures above $80^{\circ} \mathrm{C}$ and with selected protease enzymes. However, treatment with trypsin or DNase had no effect on their activity. Seven cosmid

clones from a genomic library of a T3 strain were selected for their ability to consistently inhibit a sensitive indicator strain in plate assays. Southern hybridization analysis placed these into three bacteriocin $(\mathrm{BCN})-$ producing groups designated $\mathrm{BCN}-\mathrm{A}, \mathrm{BCN}-\mathrm{B}$, and $\mathrm{BCN}-\mathrm{C}$. The $\mathrm{BCN}-$ like groups could be differentiated by variations in inhibitory spectra and levels of activity in plate assays. Mutations that inactivated expression of each BCN group individually in a wild-type T3 strain had inhibitory activity confirming that multiple BCNs are present in the T3 strain. T3 strains were inhibitory to a sensitive indicator strain in tomato leaf tissue, but this effect was observed only when T3 strains were applied in advance of the sensitive strain. $\mathrm{BCN}$-A was the major $\mathrm{BCN}$-like substance involved in the suppression of the sensitive indicator strain in tomato leaf tissues.
\end{abstract}

Xanthomonas campestris pv. vesicatoria (Doidge) Dye causes bacterial spot disease on pepper (Capsicum annuum L.) and tomato (Lycopersicon esculentum Mill.). Strains of this bacterium can be placed into groups based on the host species attacked (i.e., tomato and pepper) and into races based on the disease response on differential pepper and tomato cultivars (12). The race composition of the pathogen is variable in nature. Race shifts can occur as a result of changes in plant genotypes (12), introduction of new races on seeds or transplants (19), application of copper-based bactericides that select for strains carrying the copper-resistance plasmid and associated avrBs 1 gene (23), and differences in strain competitiveness (10). An opportunity to study the competitive nature of strains of $X$. campestris pv. vesicatoria in the same populations was recently afforded. Prior to the early 1990s, only tomato race 1 (T1) strains of the bacterium were detected on tomato plants in Florida $(3,4)$. In 1991, tomato race 3 (T3) strains of $X$. campestris pv. vesicatoria were first identified in two Florida locations (13). Within 4 years, T3 strains became dominant on tomato in commercial fields and were found in all areas of the state (10).

This race shift was particularly surprising because $\mathrm{T} 1$ strains were the only strains in Florida on tomato for the prior 30 years. Coincident with the change of race was the observation that T3 strains were inhibitory to T1 strains (6). Antibiosis is one of the factors commonly involved in microbial competition $(29,30)$.

The objectives of this study were to determine the cause of the antibiosis of T3 strains against T1 strains, define the genetic determinants responsible, and determine if the antibiosis factors, in part, explain T3 strains' ability to compete more effectively than T1 strains.

Corresponding author: J. B. Jones; E-mail address: jbjones@ufl.edu

Publication no. P-2003-0912-01R

(c) 2003 The American Phytopathological Society

\section{MATERIALS AND METHODS}

Bacterial strains, plasmids, and culture conditions. The bacterial strains and plasmids used in this study are listed in Table 1. All strains of $X$. campestris pv. vesicatoria were grown on nutrient agar (NA; Becton, Dickinson and Company, Sparks, MD) at $28^{\circ} \mathrm{C}$. Strains of Escherichia coli were grown on Luria-Bertani (LB) medium (16) at $37^{\circ} \mathrm{C}$. All strains were stored in capped tubes containing $2.0 \mathrm{ml}$ of sterile tap water at room temperature or in nutrient broth $(\mathrm{NB})$ containing $30 \%$ glycerol at $-70^{\circ} \mathrm{C}$. Antibiotics were used to maintain selection for resistance markers at the following concentrations: tetracycline (Tet), $10 \mu \mathrm{g} / \mathrm{ml}$; rifamycin (Rif), $100 \mu \mathrm{g} / \mathrm{ml}$; and spectinomycin (Spec), nalidixic acid (Nal), and kanamycin (Kan), $50 \mu \mathrm{g} / \mathrm{ml}$.

Screening for antimicrobial activity. Screening of T3 strains for the production of inhibitory products was performed with a deferred assay (25). Strains to be tested for antagonism were grown on a shaker for $18 \mathrm{~h}$ at $28^{\circ} \mathrm{C}$ in tubes containing $4 \mathrm{ml}$ of NB. The cells were pelleted and resuspended into sterile tap water. Suspensions were standardized to $A_{600}=0.3$, equating to $\approx 3 \times 10^{8} \mathrm{CFU} / \mathrm{ml}$. Twenty-five microliters was then spotted onto NA plates, five strains per plate, and incubated for $18 \mathrm{~h}$ at $28^{\circ} \mathrm{C}$. Both a positive and a negative control were plated onto each test plate. A suspension of $3 \times 10^{7} \mathrm{CFU} / \mathrm{ml}$ of the indicator strain was sprayed over the surface of the plate with an aerosol spray unit (Sigma Chemical, St. Louis). A clear zone of inhibition around test colonies after 24 to $48 \mathrm{~h}$ was considered indicative of antagonism. The width of inhibition zones was measured as the distance from the edge of the test culture to the outer edge of the zone. Each treatment was replicated four times.

Cell-free filtrates were screened for inhibitory activity. Test cultures were grown for $18 \mathrm{~h}$ in NB followed by centrifugation to pellet cells. The supernatants were then sterilized using low protein binding membrane filters (Gelman Sciences, Ann Arbor, MI) with a pore size of $0.2 \mu \mathrm{m}$ and analyzed for antagonistic activity by the well-diffusion method (26). Ten-millimeter-diameter 
wells were cut into NA plates containing $20 \mathrm{ml}$ of the medium. Two hundred microliters of filtrate was applied to each well and allowed to diffuse for $12 \mathrm{~h}$. Media were overlaid with $3.5 \mathrm{ml}$ of $0.7 \%$ molten $\left(45^{\circ} \mathrm{C}\right)$ water agar containing $200 \mu \mathrm{l}$ of a $3 \times$ $10^{8} \mathrm{CFU} / \mathrm{ml}$ suspension of the indicator strain. Strain 91-106 (T1) was used as both the negative control and indicator strain for these studies. Plates were examined after $24 \mathrm{~h}$ at $28^{\circ} \mathrm{C}$ for zones of inhibition around the wells. Each treatment was replicated four times.

Sensitivity to heat and enzymes. Cell-free filtrates were assessed for their sensitivity to various enzyme and heat treatments. Temperature stability was determined by heating $200 \mathrm{ml}$ of culture filtrate to 65,80 , or $100^{\circ} \mathrm{C}$ for 10,20 , or $30 \mathrm{~min}$, respectively. After heat treatments, 200- $\mu$ l samples were assayed for activity by the well-diffusion method. The enzymes and their buffers were pronase (Sigma) in $5 \mathrm{mM}$ Tris- $\mathrm{HCl}(\mathrm{pH} 7.3)$ with $10 \mathrm{mM}$ $\mathrm{CaCl}_{2}$; proteinase $\mathrm{K}$ (Boehringer Mannheim Biochemicals, Indianapolis) in $50 \mathrm{mM}$ Tris- $\mathrm{HCl}\left(\mathrm{pH} \mathrm{7.3)}\right.$ with $5 \mathrm{mM} \mathrm{CaCl}_{2}$; trypsin (Sigma) in $50 \mathrm{mM}$ Tris- $\mathrm{HCl}$ (pH 7.9) with $5 \mathrm{mM} \mathrm{CaCl}_{2}$; and DNase (Promega, Madison, WI) in $40 \mathrm{mM}$ Tris- $\mathrm{HCl}$ (pH 7.9) with $10 \mathrm{mM} \mathrm{NaCl}, 6 \mathrm{mM} \mathrm{MgCl} 2$, and $10 \mathrm{mM} \mathrm{CaCl}_{2}$. Enzymes were tested at a final concentration of $1 \mathrm{mg} / \mathrm{ml}$, except for pronase and trypsin which were tested at final concentrations of 100 and $200 \mu \mathrm{g} / \mathrm{ml}$, respectively. The mixtures were incubated for $2 \mathrm{~h}$ at $37^{\circ} \mathrm{C}$, except for samples containing trypsin, which were incubated at $24^{\circ} \mathrm{C}$. Prior to assaying for antagonistic activity, preparations containing trypsin and proteinase $\mathrm{K}$ were treated with protease inhibitors. Trypsin was inhibited using type II-0 Ovoinhibitor (Sigma) at a final concentration of $1 \mathrm{mg} / \mathrm{ml}$. Proteinase $\mathrm{K}$ was treated with $170 \mu \mathrm{g}$ of phenylmethylsulfonyl fluoride (Sigma) per $\mathrm{ml}$ according to the manufacturer's instructions. After enzyme treatments, $200-\mu \mathrm{l}$ samples were assayed for remaining activity by the well-diffusion method.

Test for bacteriophage activity. The possible involvement of bacteriophages was tested by determining if the inhibitor agent could be transferred in the absence of the bacterium by two different methods. In the first method, agar plugs of 2-mm diameter were removed from inhibition zones and crushed in $500 \mu \mathrm{l}$ of NB. Fifty microliters of chloroform was added, and the mixture was vortexed vigorously and then centrifuged at $14,000 \times g$ for $1 \mathrm{~min}$. Fifty microliters of the top phase was removed and added to $450 \mu \mathrm{l}$ of sterile deionized water. Five serial 10-fold dilutions were made. Five hundred microliters of each was added to $3.5 \mathrm{ml}$ of melted $0.7 \%$ water agar $\left(50^{\circ} \mathrm{C}\right)$ in tubes containing $200 \mu \mathrm{l}$ of the indicator strain (75-3) and plated on the surface of an NA plate. Each dilution was plated in duplicate. After incubating for $24 \mathrm{~h}$ at $28^{\circ} \mathrm{C}$, plates were examined for the presence of plaques. Cell-free filtrates with inhibitory activity were examined by electron microscopy for the presence of bacteriophage particles on Formvar-coated grids washed with distilled water and negatively stained with $1 \%$ uranyl acetate.

Another method was used to screen for chloroform-sensitive bacteriophages. A thin layer of agar was removed with a sterile loop from the surface of the zone between a T3 producing strain and a T1 sensitive strain, 91-106. The loop was quadrant streaked over the agar surface in a petri dish containing a lawn of a 24-hold suspension of 91-106. The plates were assessed for the appearance of plaques after $24 \mathrm{~h}$ incubation at $28^{\circ} \mathrm{C}$. A positive control was used in which similar plates were quadrant streaked with a T1 bacteriophage.

DNA manipulations and genetic techniques. Standard procedures were used for plasmid isolation, restriction endonuclease digestion, agarose gel electrophoresis, and Southern hybridizations (21). A cosmid library of purified DNA from $X$. campestris pv. vesicatoria strain 91-118 was screened. The library was constructed in the cosmid vector pLAFR3 $\left(\mathrm{Tet}^{\mathrm{r}}\right)$ (24) and maintained in $E$. coli strain DH5 $\alpha$. Each cosmid clone was conjugated into $X$. campestris pv. vesicatoria strain ME90 $\left(\operatorname{Rif}^{\mathrm{r}}, \mathrm{Kan}^{\mathrm{r}}\right)$ using triparental mating as described previously (2). Cosmid clones ( Tet $^{r}$ ) were used as donor strains, strain ME90 as the recipient and pRK2073 $\left(\mathrm{Spec}^{\mathrm{r}}\right)$ as the helper plasmid. All three strains were mixed on nutrient yeast-glucose agar (5) and incubated at $28^{\circ} \mathrm{C}$ for $24 \mathrm{~h}$. The mixture was resuspended in sterile tap water and

TABLE 1. Strains and plasmids used in study

\begin{tabular}{|c|c|c|}
\hline Strain or plasmid & Relevant characteristics & Source or reference ${ }^{a}$ \\
\hline \multicolumn{3}{|c|}{ Xanthomonas campestris pv. vesicatoria } \\
\hline $75-3$ & T1 strain, BCN sensitive & RES \\
\hline $91-118$ & $\mathrm{~T} 3$ strain, $\mathrm{BCN}$ producing & RES \\
\hline $91-118 \mathrm{R}$ & Rif $^{r}$ & This study \\
\hline $91-106$ & T1 strain, BCN sensitive & RES \\
\hline $91-106 \mathrm{R}$ & Rif $^{\mathrm{r}}$ & This study \\
\hline ME90 & $\operatorname{Rif}^{r} \operatorname{Kan}^{r}$ & Bonas et al. (2) \\
\hline ME-A & $\mathrm{BCN}^{-} \mathrm{A}^{-} \mathrm{B}^{+} \mathrm{C}^{+}$ & This study \\
\hline ME-B & $\mathrm{BCN}^{-} \mathrm{A}^{+} \mathrm{B}^{-} \mathrm{C}^{+}$ & This study \\
\hline ME-C & $\mathrm{BCN}^{-} \mathrm{A}^{+} \mathrm{B}^{+} \mathrm{C}^{-}$ & This study \\
\hline \multicolumn{3}{|l|}{ Escherichia coli } \\
\hline HB101 & $\mathrm{F}^{-} \operatorname{rec} \mathrm{A}$ & BRL \\
\hline DH5 $\alpha$ & $\mathrm{F}^{-} \operatorname{rec} \mathrm{A}$ & BRL \\
\hline $\mathrm{C} 2110$ & $\mathrm{Nal}^{\mathrm{r}}$ & BRL \\
\hline \multicolumn{3}{|l|}{ Plasmids } \\
\hline pLAFR3 & tet $^{\mathrm{r}} r l x^{+} \mathrm{RK} 2$ replicon & Staskawicz et al. (24) \\
\hline pRK2073 & Spec $^{\mathrm{r}} \mathrm{tra}^{+} \mathrm{mob}^{+}$ & Figurski and Helinski (8) \\
\hline pHoKmGus & $\operatorname{Kan}^{\mathrm{r}} \mathrm{Amp}^{\mathrm{r}} \operatorname{tnp} A^{-}$contains promoterless $\beta$-glucuronidase gene & BJS \\
\hline pXV120 & pLAFR3 cosmid clone from $X$. campestris pv. vesicatoria strain $91-118\left(\mathrm{BCN}^{-\mathrm{C}^{+}}\right)$ & Tudor (27) \\
\hline pXV442 & pLAFR3 cosmid clone from $X$. campestris pv. vesicatoria strain 91-118 (BCN-B $)$ & Tudor (27) \\
\hline pXV501 & 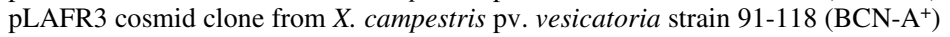 & This study \\
\hline pXV519 & pLAFR3 cosmid clone from $X$. campestris pv. vesicatoria strain 91-118 (BCN-A $\left.{ }^{+}\right)$ & Tudor (27) \\
\hline pXV344 & pLAFR3 cosmid clone from $X$. campestris pv. vesicatoria strain 91-118 & This study \\
\hline pXV699 & pLAFR3 cosmid clone from $X$. campestris pv. vesicatoria strain 91-118 (BCN-B $\left.{ }^{+}\right)$ & This study \\
\hline pXV711 & pLAFR3 cosmid clone from $X$. campestris pv. vesicatoria strain $91-118\left(\mathrm{BCN}^{\left.-\mathrm{A}^{+}\right)}\right.$ & This study \\
\hline pXV717 & pLAFR3 cosmid clone from $X$. campestris pv. vesicatoria strain 91-118 & This study \\
\hline pXV754 & pLAFR3 cosmid clone from $X$. campestris pv. vesicatoria strain $91-118\left(\mathrm{BCN}^{\left.-\mathrm{A}^{+}\right)}\right.$ & This study \\
\hline pXV878 & pLAFR3 cosmid clone from $X$. campestris pv. vesicatoria strain 91-118 & This study \\
\hline pXV933 & pLAFR3 cosmid clone from $X$. campestris pv. vesicatoria strain 91-118 & This study \\
\hline
\end{tabular}

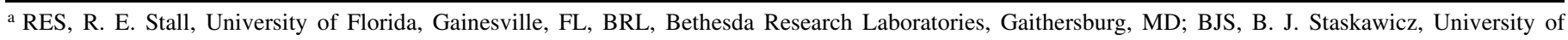
California, Berkeley. 
plated onto NA containing rifamycin, kanamycin, and tetracycline. Purified transconjugants were transferred onto NA plates and screened for antagonism against strain 91-106 as described previously. Seven hundred fifty clones, each containing 15 to $30 \mathrm{~kb}$ of insert DNA, were screened for antagonistic activity. Transconjugants surrounded by clear zones of inhibition were selected for further study. Expression of bacteriocin (BCN) activity of selected transconjugants also was tested in four other recipients (T1 strains) and against several other indicator strains.

Clones with BCN activity in T1 strains were used in crosshybridization experiments with each other. Insertion mutagenesis of $\mathrm{BCN}$ clones was performed using the $\mathrm{Tn} 3 \mathrm{HoHo}$ derivative, pHoKmGus (provided by D. Dahlbeck and B. Staskawicz, University of California, Berkeley). The protocol used was as follows: E. coli strain HB101 (pHoKmGus) was transformed with plasmid DNA isolated from a BCN clone. Transformants $\left(\mathrm{Tet}^{\mathrm{r}}\right.$ $\left.\mathrm{Kan}^{\mathrm{r}}\right)$ were then mated with E. coli C2110 $\left(\mathrm{Nal}^{\mathrm{r}}\right)$ using pRK2073 as the helper plasmid (2). Matings were plated on LB agar plates amended with tetracycline, kanamycin, and nalidixic acid. Insertion derivatives were mobilized into $X$. campestris pv. vesicatoria strain ME90 as described previously and screened for loss of BCN activity against strain 91-106. Confirmation of insertions was made by restriction endonuclease analysis.

Marker exchange was performed using triparental matings with $\mathrm{BCN}^{-}$insertion mutants $\left(\mathrm{Tet}^{\mathrm{r}} \mathrm{Kan}^{\mathrm{r}}\right.$ ) as donors, 91-118R $\left(\mathrm{Rif}^{\mathrm{r}}\right)$ as the recipient and pRK2073 as the helper plasmid. The rifamycinresistant $91-118 \mathrm{R}$ strain was previously isolated by plating $10^{9}$ cells of wild-type 91-118 onto NA amended with rifamycin, followed by selection of resistant colonies with wild-type BCN and pathogenicity characteristics. Transconjugants were selected on NA amended with tetracycline, kanamycin, and rifamycin. They were then serially transferred daily for 10 days onto NA amended with kanamycin and rifamycin. At the end of the transfer schedule, dilutions were plated onto a phosphate medium (NA containing $10 \mathrm{~g}$ of $\mathrm{NaH}_{2} \mathrm{PO}_{4}$ per liter) containing kanamycin and rifamycin. Single colonies were screened on a medium containing all three antibiotics. Colonies that were unable to grow on this medium $\left(\right.$ Tet $\left.^{\mathrm{s}} \mathrm{Kan}^{\mathrm{r}} \mathrm{Rif}^{\mathrm{r}}\right)$ were selected to represent those in which a successful recombination event had occurred with concomitant loss of the introduced plasmid (pLAFR3). These were then tested for loss of $\mathrm{BCN}$ activity. Confirmation was obtained by probing marker exchange mutants with a probe derived from the transposable element used to generate the mutants.

Plant assays. Leaflets of 6-week-old seedlings of the tomato cultigen Florida 7060 were infiltrated with bacterial suspensions of both the producer and the indicator strains with a hypodermic syringe as described previously (10). Prior to inoculation, strains were grown in NB for $18 \mathrm{~h}$, harvested by centrifugation, and resuspended in sterile tap water. Suspensions of producer and sensitive strains were infiltrated into fully expanded leaflets at the same time or into the same area with the producer strain inoculated $12 \mathrm{~h}$ prior to the sensitive indicator strain. Concentrations of the producer strains and indicator strains were $5 \times 10^{7}$ and $5 \times 10^{6} \mathrm{CFU} / \mathrm{ml}$, respectively. Each treatment consisted of three replications. Plants were incubated between 24 and $28^{\circ} \mathrm{C}$. The indicator strain populations in leaflets of each treatment were quantified by removing $1-\mathrm{cm}^{2}$ leaf disks from inoculated areas, macerating in $1 \mathrm{ml}$ of sterile tap water, and plating 10-fold dilutions onto NA amended with the appropriate antibiotic. Populations were determined at 12- to 24-h intervals. Each experiment was repeated at least twice with three replicates per treatment.

\section{RESULTS}

Screen for antimicrobial activity. None of the $X$. campestris pv. vesicatoria $\mathrm{T} 3$ strains were sensitive to antagonism caused by the T3 producer-strain 91-118 (Table 2), whereas all X. campestris pv. vesicatoria strains classified as T1 were inhibited by strain 91-
118. Zones of inhibition ranged from $6 \mathrm{~mm}$ against strain 6107 to $1 \mathrm{~mm}$ against strain BV55. T2 strains were variable in their sensitivity to inhibition by strain 91-118. Twelve of the twenty-four pathovars of $X$. campestris screened were sensitive to antagonism by strain 91-118. None of the other bacterial genera tested were sensitive (Table 2). Sterile culture filtrates of $X$. campestris $\mathrm{pv}$. vesicatoria strain 91-118 were inhibitory to indicator strain 75-3.

Sensitivity to heat and enzymes. Antagonistic activity against strain 75-3 (sensitive) was detected with cell-free filtrates held at $65^{\circ} \mathrm{C}$ for $30 \mathrm{~min}$. However, when filtrates were held at temperatures of $80^{\circ} \mathrm{C}$ and above for $10 \mathrm{~min}$ or longer, activity was lost. Treatment of culture filtrates with pronase and proteinase $\mathrm{K}$ resulted in the inactivation of antagonism. Treatment of filtrates with trypsin and DNase had no effect on activity.

Test for antagonism due to bacteriophage. No plaques were observed in lawns after $24 \mathrm{~h}$ of incubation. Thus, the inhibitory agent had not replicated in the indicator strain. No phage-like structures were identified in culture filtrates of strain 91-118 by

TABLE 2. Diameter of inhibition zones caused by tomato race 3 strains of Xanthomonas campestris pv. vesicatoria against other bacterial strains

\begin{tabular}{|c|c|c|}
\hline Strain & Race & $\begin{array}{c}\text { Diameter of } \\
\text { inhibition } \\
\text { zone }(\mathrm{mm})^{\mathrm{a}}\end{array}$ \\
\hline \multicolumn{3}{|l|}{ X. campestris pv. vesicatoria } \\
\hline \multicolumn{3}{|l|}{ 91-108, 91-106, 92-40, 92-51, 92-47, 93-29, } \\
\hline \multicolumn{3}{|c|}{$91-111,80-5,94-1,93-1,1712,90-60,92-17$, } \\
\hline \multirow{2}{*}{\multicolumn{3}{|c|}{$\begin{array}{l}92-16,91-66, \text { XV14, 89-8, 89-10, 75-3, 90-40, } \\
87-44,87-21,1522,1520,87-35,1521\end{array}$}} \\
\hline & & \\
\hline $90-21,87-13$ & $\mathrm{~T} 1$ & 1 \\
\hline 6107 & $\mathrm{~T} 1$ & 6 \\
\hline 10, MM-E, BA28-1, BV55, 0350A & $\mathrm{T} 2$ & $1-3$ \\
\hline $92-48,9,18,19$, MM-G, 90-20, 0226A & $\mathrm{T} 2$ & 0 \\
\hline $1483,1484,91-118$ & $\mathrm{~T} 3$ & 0 \\
\hline \multicolumn{3}{|l|}{ X. campestris } \\
\hline pv. alfalfae & - & 3 \\
\hline pv. amoraceae & - & 0 \\
\hline pv. begoniae & - & 3 \\
\hline pv. campestris & - & 0 \\
\hline pv. carotae & - & 0 \\
\hline pv. celebensis & - & 3 \\
\hline pv. corylina & - & 0 \\
\hline pv. dieffenbachiae & - & 2 \\
\hline pv. fici & - & 0 \\
\hline pv. glycines & - & 3 \\
\hline pv. graminis & - & 3 \\
\hline pv. holcicola & - & 2 \\
\hline pv. juglandis & - & 0 \\
\hline pv. maculifoliigardeniae & - & 0 \\
\hline pv. pelargonii & - & 1 \\
\hline pv. phaseoli & - & 2 \\
\hline pv. phaseoli var. fuscans & - & 0 \\
\hline pv. physalidicola & - & 0 \\
\hline pv. pisi & - & 0 \\
\hline pv. poae & - & 1 \\
\hline pv. strelitzia & - & 0 \\
\hline pv. taraxici & - & 3 \\
\hline pv. translucens & - & 0 \\
\hline pv. vitians & - & 1 \\
\hline Agrobacterium tumefaciens & - & 0 \\
\hline Erwinia stewartii & - & 0 \\
\hline \multicolumn{3}{|l|}{ Pseudomonas syringae } \\
\hline pv. syringae & - & 0 \\
\hline pv. tomato & - & 0 \\
\hline Xanthomonas fragariae & - & 0 \\
\hline Stenotrophomonas maltophilia & - & 0 \\
\hline Clavibacter michiganensis & - & 0 \\
\hline subsp. michiganensis & - & 0 \\
\hline subsp. sepedonicus & - & 0 \\
\hline subsp. insidiosus & - & 0 \\
\hline Clavibacter rathayi & - & 0 \\
\hline
\end{tabular}

${ }^{a}$ Width of inhibition zone measured as the distance from the edge of the test culture to the outer edge of the zone. Represents an average of four replicates. Indicator strain applied by spray to plates. 
electron microscopy. No plaques from the zone were observed with the quadrant streaking method, but visible plaques were observed with the positive bacteriophage control.

Screen of cosmid library. Cosmid clones mobilized into $X$. campestris pv. vesicatoria strain ME-90 conferred antagonistic activity when tested against the indicator strain 91-106. These clones were divided into three groups based on cross-hybridization experiments: BCN-A consisted of pXV501, pXV519, pXV711, and pXV754; BCN-B consisted of pXV442 and pXV699; and BCN-C consisted solely of pXV120. No activity was detected in the $E$. coli strain in which the library was maintained.

Differences between BCN groups. Differences between in vitro inhibitory activity of a sensitive strain containing each clone were observed among the three groups (Fig. 1A). The strain containing the BCN-A clones consistently produced the largest zones of inhibition, even larger than those of the wild-type T3 strain, whereas BCN-C activity consistently produced the smallest zones of inhibition. Activity in nonconcentrated cell-free filtrates occurred only with the clones for the BCN-A group (Fig. 1B).
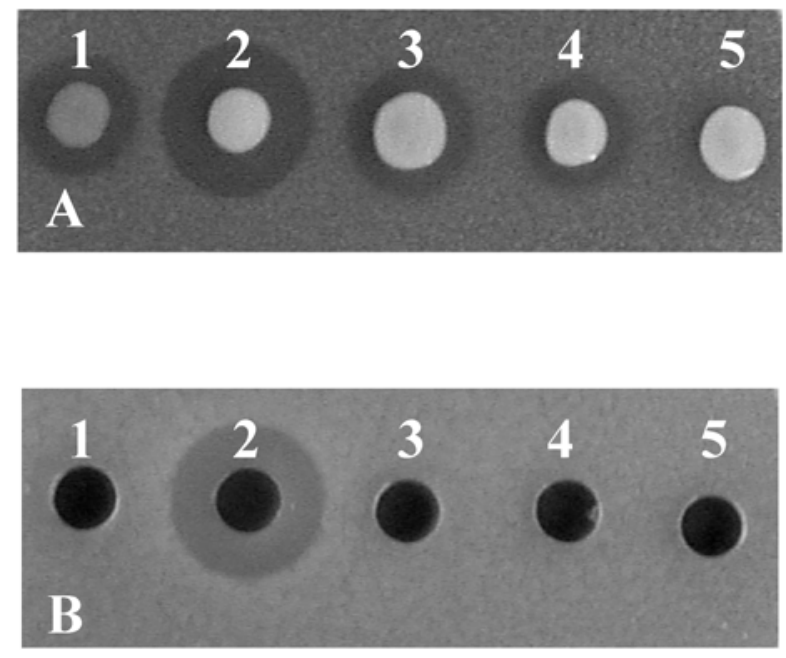

Fig. 1. Assays of bacteriocin (BCN)-like activity against Xanthomonas campestris pv. vesicatoria strain 91-106. Included in the assays were A, viable cell cultures and $\mathbf{B}$, cell-free supernatants. Plate designations were as follows: lane 1, 91-118 $\left(\mathrm{BCN}^{+}\right)$; lane 2, pXV519 in ME90 $\left(\mathrm{BCN}^{+} \mathrm{A}^{+}\right)$; lane 3,

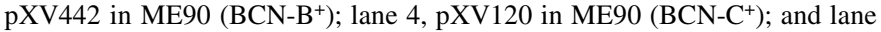
5 , pLAFR3 in ME90.

TABLE 3. Differential inhibition of selected Xanthomonas campestris pv. vesicatoria indicator strains by the three identified groups of bacteriocin $(\mathrm{BCN})$-like activity (BCN-A, BCN-B, and BCN-C) ${ }^{\mathrm{a}}$

\begin{tabular}{lcccc}
\hline Indicator strain & Tomato race & BCN-A & BCN-B & BCN-C \\
\hline $92-51$ & T1 & - & + & + \\
M103B & T1 & ++ & + & + \\
$91-106$ & T1 & ++ & + & + \\
$91-108$ & T1 & ++ & + & + \\
$91-111$ & T1 & + & - & - \\
$92-40$ & T1 & - & + & - \\
$93-29$ & T1 & ++ & + & + \\
XV14 & T1 & ++ & - & - \\
10 & T2 & + & - & - \\
XV56 & T2 & + & - & - \\
19 & T2 & + & - & - \\
$92-48$ & T2 & + & - & - \\
$91-118$ & T3 & - & - & - \\
\hline
\end{tabular}

a Width of inhibition zones measured as the distance from edge of test culture to the outer edge of the zone (millimeters). Measurements were used to assign three phenotypes which were scored as noninhibition (-), weak inhibition (zone diameters less than or equal to $4 \mathrm{~mm})(+)$, and strong inhibition (zone diameters greater than $4 \mathrm{~mm})(++)$. Each treatment was replicated four times. Strains were provided by R. E. Stall, Plant Pathology Department, University of Florida, Gainesville.
The BCN groups had differential inhibition patterns against selected $X$. campestris pv. vesicatoria indicator strains (Table 3). All T1 strains tested were susceptible to at least one of the BCN groups, whereas T2 strains were sensitive only to BCN-A. Some T1 strains, such as strain 91-106, which was used as the standard indicator strain for most experiments, were sensitive to all three groups. A wild-type T3 strain was not sensitive to any of the BCN-like activities.

Mutagenesis. Transposon insertion mutations in clones were obtained for the three $\mathrm{BCN}$ groups. Using these, marker exchange mutants for each of the wild-type loci in strain 91-118 were obtained and designated ME-A, ME-B, and ME-C. These mutants retained detectable levels of $\mathrm{BCN}$ activity (data not shown).

Plant assays. The population size of a sensitive strain in planta at $48 \mathrm{~h}$ after inoculation into tomato leaves was approximately $10^{4} \mathrm{CFU} / \mathrm{cm}^{2}$ less when a T3 strain (91-118) was applied $12 \mathrm{~h}$ prior to the exact same area of the leaf (Fig. 2). However, this reduction was not observed when the indicator strain and producer strain were inoculated simultaneously. The wild-type T1 strain did not significantly inhibit growth of the indicator strain in similar experiments, although relative to the water control, growth was slightly reduced.

Clones corresponding to each of the BCN groups were individually mobilized into $X$. campestris pv. vesicatoria strain ME90 and tested for their ability to inhibit the sensitive indicator T1 strain (91-106) in the tomato genotype 7060 when applied $12 \mathrm{~h}$ before the indicator strain. Both the wild-type T3 strain and the strain containing the $\mathrm{BCN}-\mathrm{A}$ clone reduced the growth of the indicator strain by approximately 100- and 10,000-fold, respectively, over a 72-h period (Fig. 3). In contrast, the population size of the indicator strain increased in the presence of a wild-type $\mathrm{T} 1\left(\mathrm{BCN}^{-}\right)$ strain and strains with $\mathrm{BCN}-\mathrm{B}$ and $\mathrm{BCN}-\mathrm{C}$ clones. The $\mathrm{T} 3$ strains with single mutations at each of the $\mathrm{BCN}$ loci were tested for their ability to inhibit a sensitive T1 strain when applied to tomato

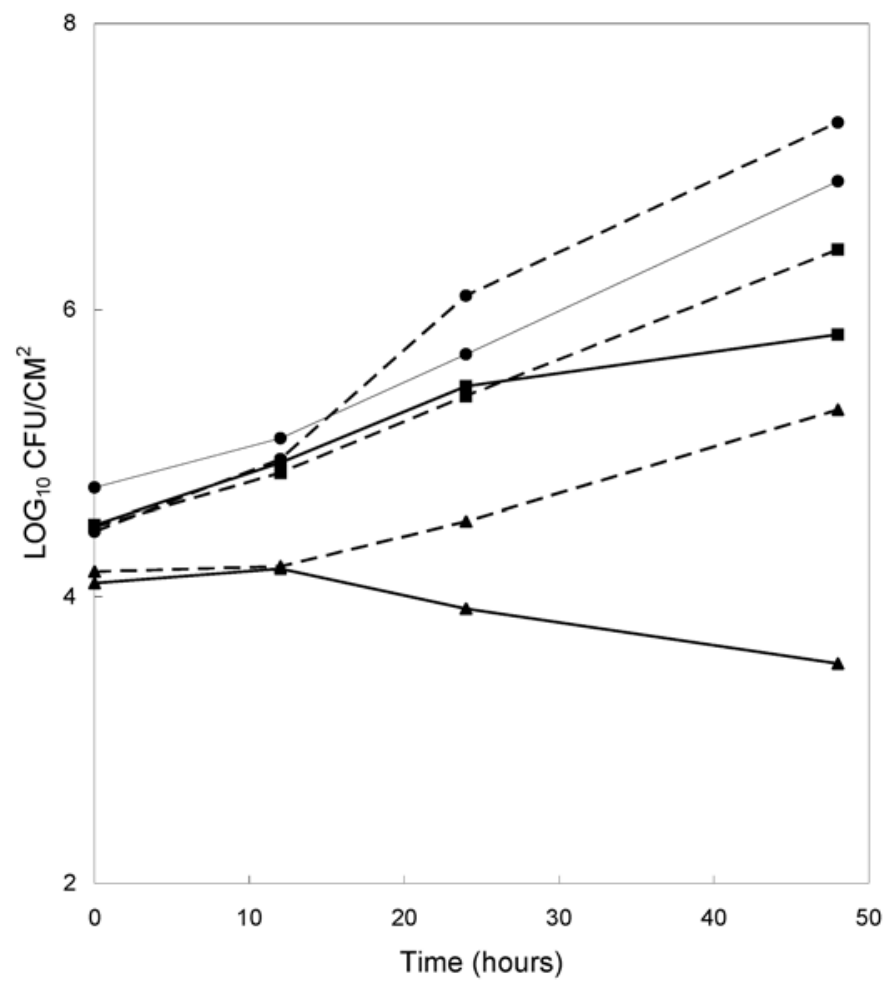

Fig. 2. Time course of growth of Xanthomonas campestris pv. vesicatoria indicator strain 91-106 in tomato cultigen 7060 when inoculated at the same time (dashed line) or $12 \mathrm{~h}$ after treatments (solid line). Bacterial populations in leaves were sampled every 12 to $24 \mathrm{~h}$ for $48 \mathrm{~h}$ following infiltration with sterile tap water $(\bullet), 75-3\left(\mathrm{BCN}^{-}\right)(\mathbf{\bullet})$, and $91-118\left(\mathrm{BCN}^{+}\right)(\mathbf{\Delta})$. Results represent means of three independent experiments. 
leaflets $12 \mathrm{~h}$ earlier. Growth of the indicator strain was restricted in the presence of the wild-type T3 strain and marker exchange strains containing mutations at the $\mathrm{BCN}-\mathrm{B}$ and $\mathrm{BCN}-\mathrm{C}$ loci (Fig. 4). However, a wild-type T3 strain mutated at the BCN-A locus only slightly inhibited the growth of the sensitive strain.

\section{DISCUSSION}

The production of an antagonistic compound against selected strains of $X$. campestris pv. vesicatoria was a trait that was uniformly found among the T3 strains tested. The substance causing antagonism was secreted extracellularly and was diffusible through agar media. In reports in which in vitro antagonism was attributed to metabolic by-products, the producer culture was always autosensitive (20). The opposite is true of BCN production $(14,29)$. In the case of the observed antagonism, strain 91-118 was not sensitive to its own antagonistic agent, indicating that the phenomenon is unrelated to production of a toxic nonspecific metabolic by-product. Inactivation of the antagonistic properties of culture filtrates of strain 91-118 at temperatures of $80^{\circ} \mathrm{C}$, and with pronase and proteinase $\mathrm{K}$, indicates the involvement of a biologically active protein component, a characteristic shared by most BCNs.

Not all $X$. campestris pv. vesicatoria strains were equally sensitive to inhibition by T3 strains. There are four distinct groups within the bacterial spot of tomato pathogens $(11,22)$. These groups are designated A through D. Strains belonging to these groups can be differentiated phenotypically and genetically. Sensitivity to the BCN-like compounds secreted by T3 strains represents another way that they differ as shown in Table 2.

8

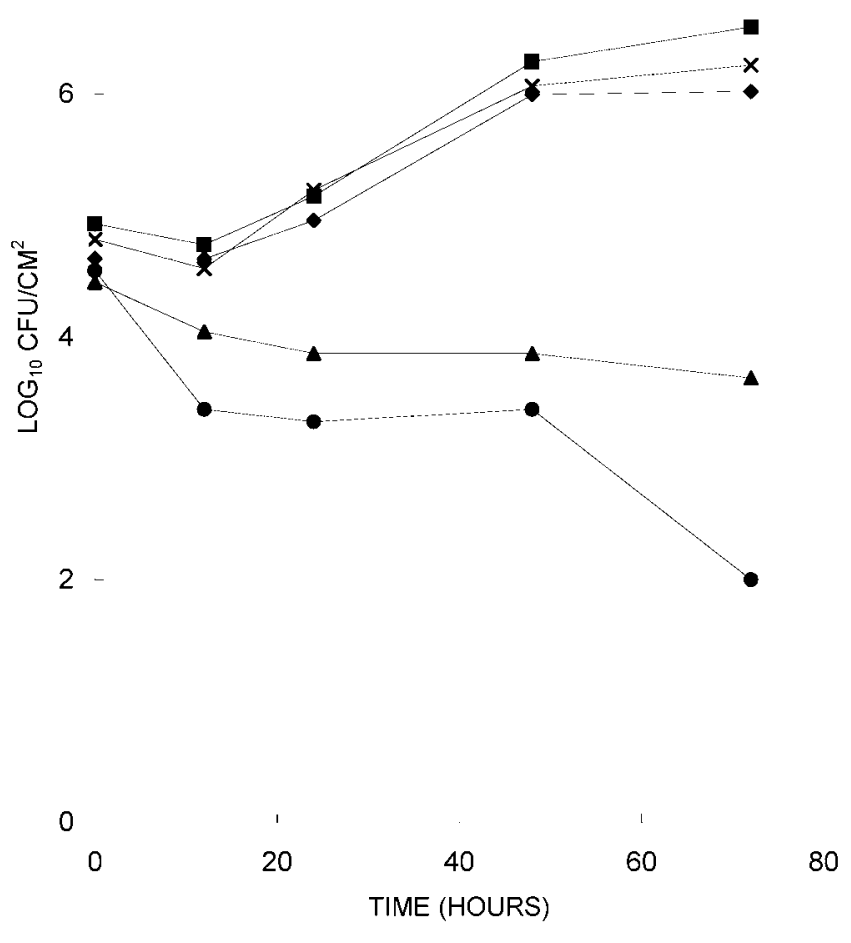

Fig. 3. Time course of multiplication of Xanthomonas campestris pv. vesicatoria indicator strain 91-106 in tomato cultigen 7060. Bacterial populations in leaves were sampled every 12 to $24 \mathrm{~h}$ for $72 \mathrm{~h}$ following infiltration with wild-type T1 strain 75-3 $\left(\mathrm{BCN}^{-}\right)(\mathbf{\bullet})$, T3 strain $91-118$ $(\mathrm{BCN})(\boldsymbol{\bullet}), \mathrm{pXV} 519(\mathrm{BCN}-\mathrm{A})(\bullet), \mathrm{pXV} 442(\mathrm{BCN}-\mathrm{B})(\bullet)$, and pXV120 $(\mathrm{BCN}-\mathrm{C})(\mathbf{X})$. All plasmids were transferred to $X$. campestris pv. vesicatoria strain ME90 prior to testing.
The pathovars of $X$. campestris that were screened were also differentially sensitive to antagonism by T3 strains. A number of DNA homology groups were described within Xanthomonas spp. (28), some of which contain pathovars that attack related hosts, whereas others do not share this similarity. The sensitive pathovars from this study did not fit into a single homology group; therefore, this common trait is contrary to their genetic relatedness. Xanthomonad species were the only bacteria inhibited by the putative $\mathrm{BCN}$. The compound therefore has a very narrow inhibitory spectrum, a characteristic shared by BCNs.

The antagonism of T3 strains to other strains of the bacterium was demonstrated to be associated with at least three different regions of DNA encoding for inhibitory activity. Four additional clones were isolated from the T3 genomic library; however, because of inconsistencies of antagonism in plate assays, they were not characterized further. Similar inconsistencies were observed in the BCN-like activity of Pseudomonas solanacearum (9). Marker exchange mutants of a wild-type strain at each of the three loci were still antagonistic, further confirming the production of compounds, which are expressed independently of each other.

The production of multiple BCN-like compounds by a single bacterial strain is rare (29) but has been reported to occur in bacteria such as $X$. campestris pv. glycines and Leuconostoc spp. $(1,7,18)$. The former $(7)$ was based on findings that the BCNs (of a single strain) directed toward the different indicator strains were variably sensitive to protease and heat treatments. However, these activities were neither resolved nor demonstrated to occur independently. In another study, five cosmid clones conferring $\mathrm{BCN}$ like activity were isolated from an $X$. campestris pv. glycines cosmid library (1). Cross-hybridization experiments with these clones revealed the presence of multiple $\mathrm{BCN}$-like activities within the single strain. However, the activities were not separated and differences between them were not examined further. Interestingly, a

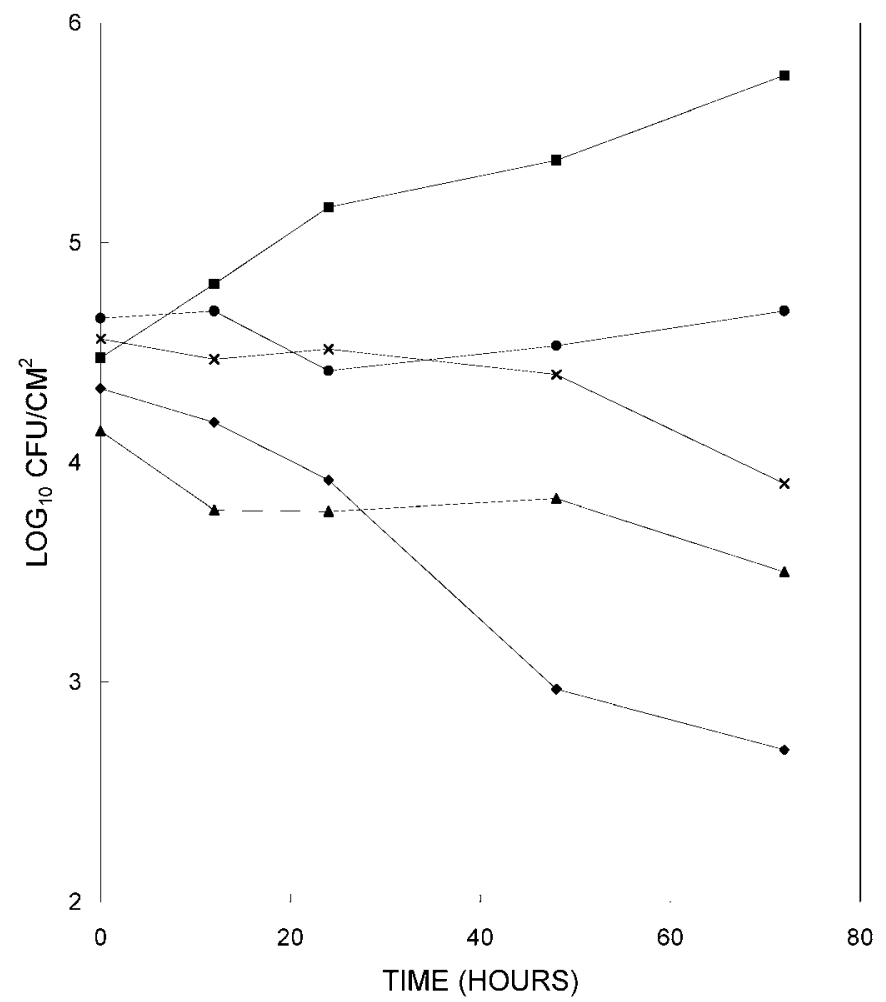

Fig. 4. Time course of multiplication of Xanthomonas campestris pv. vesicatoria indicator strain 91-106 in tomato cultigen 7060. Bacterial population in leaves were sampled every 12 to $24 \mathrm{~h}$ for $72 \mathrm{~h}$ following infiltration with strains 75-3 (T1) $\left(\mathrm{BCN}^{-}\right)(\mathbf{-})$, 91-118 (T3) $\left(\mathrm{BCN}^{+}\right)$

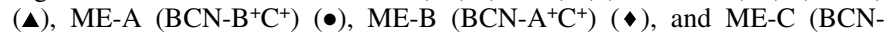
$\left.\mathrm{A}^{+} \mathrm{B}^{+}\right)(\mathbf{x})$. 
strain of $X$. campestris pv. glycines that produced BCNs (7) was inhibitory to some strains of $X$. campestris pv. vesicatoria.

$\mathrm{T} 3$ strains were inhibitory to $\mathrm{T} 1$ indicator strains in leaves of a susceptible tomato genotype, providing evidence of a direct selective advantage for T3 strains in the infection court. The coexistence of multiple races within a single leaf lesion in the field was documented (17), an indication that site competition may occur between two strains in a susceptible host. Reduction in the indicator strain population level was comparable to the reduction in populations achieved in the hypersensitive response of tomato line Hawaii 7998 to T1 strains (31). Similar growth levels of both producer and indicator strains independently in tomato leaves indicate that inhibition of the indicator strains is not the result of a plant effect. Antagonism, however, only occurred when T3 strains were preemptive. These results prompt speculation that the major use of these types of compounds in biocontrol strategies would be prophylactic rather than curative (29). In a recent study, a nonpathogenic T3 strain of $X$. campestris pv. vesicatoria was shown to reduce the severity of bacterial spot disease in the field when applied prophylactically (15).

Results of in planta antagonism studies indicate that BCN-A expression is an essential and dominant component in the suppression of a sensitive indicator strain in tomato leaf tissues. When expressed singly in a $\mathrm{T} 1$ strain, $\mathrm{BCN}-\mathrm{A}$ inhibited indicator strain populations to an even greater extent than the wild-type T3 strain. However, the other two BCN-like compounds were insufficient on their own. Further evidence that BCN-A was the dominant component involved was obtained when a T3 mutant insertionally inactivated at this locus exhibited a much reduced inhibitory effect to the $\mathrm{BCN}$-sensitive strain in vitro and in vivo. Inhibition of an indicator strain in tomato leaf tissues by $\mathrm{BCN}-\mathrm{A}$, coupled with the confirmation that it is produced in plant tissues, provides strong correlative evidence that $\mathrm{BCN}-\mathrm{A}$ could play a major role in mediating the population dynamics between $X$. campestris $\mathrm{pv}$. vesicatoria strains in tomato leaf tissues.

This study and others (10) have provided some initial insights as to the potential use of BCN-like producer strains in the biological control of bacterial spot disease on tomato. The lack of effective control measures to manage this disease justifies further investigation of this strategy, perhaps involving a more thorough screen for these types of compounds. In this case, identification of a compound with activity against T3 strains would be particularly useful.

A strain capable of producing several compounds against competitors likely has a selective advantage in natural ecosystems. In fact, the gradual increase of T3 strains of $X$. campestris $\mathrm{pv}$. vesicatoria in tomato populations in Florida (10) may be a reflection of this phenomenon. Until 1991, T3 strains were not found in Florida; however, in field surveys over the following 4 years, T3 strains became increasingly predominant, and as of 1995 represented some $55 \%$ of the total strains isolated from tomato fields. Given that all T1 strains tested in the present study were susceptible to at least one of the BCN-like activities and that the T3 strains have increased in prevalence compared with $\mathrm{T} 1$ strains in Florida, it is very tempting to speculate that the antagonism between these strains has played a role in this race shift. In addition, no other obvious factors commonly associated with race shifts within populations could be identified in this situation (10).

\section{ACKNOWLEDGMENTS}

This research was supported by the Florida Agricultural Experiment Station and approved for publication as Journal Series No. R-09536, and by the U.S. Department of Agriculture (USDA) T-STAR (R. E. Stall and J. B. Jones, USDA 95-34135-1764).

\section{LITERATURE CITED}

1. Ahn, E. J., and Cho, Y. S. 1996. Cloning of the bacteriocin gene from Xanthomonas campestris pv. glycines 8ra. (Abstr.) Kor. J. Plant Pathol.
47:480-487.

2. Bonas, U., Schulte, R., Fenselau, S., Minsavage, G. V., Staskawicz, B. J., and Stall, R. E. 1991. Isolation of a gene cluster from Xanthomonas campestris pv. vesicatoria that determines pathogenicity and the hypersensitive response on pepper and tomato. Mol. Plant-Microbe Interact. 4:81-88.

3. Bouzar, H., Jones, J. B., Stall, R. E., Hodge, N. C., Minsavage, G. V., Benedict, A. A., and Alvarez, A. M. 1994. Physiological, chemical, serological and pathogenic analyses of a worldwide collection of Xanthomonas campestris pv. vesicatoria strains. Phytopathology 84:663671.

4. Bouzar, H., Minsavage, G. V., Stall, R. E., and Scott, J. W. 1994. Proteins unique to phenotypically distinct groups of Xanthomonas campestris pv. vesicatoria revealed by silver staining. Phytopathology 84:39-44.

5. Daniels, M. J., Barber, C. E., Turner, P. C., Cleary, W. G., and Sawczyc, M. 1984. Isolation of mutants of Xanthomonas campestris pv. campestris showing altered pathogenicity. J. Gen. Microbiol. 130:2447-2455.

6. El-Morsy, G. A., Somodi, G. C., Scott, J. W., Stall, R. E., and Jones, J. B. 1994. Aggressiveness of Xanthomonas campestris pv. vesicatoria tomato race 3 (T3) strains over tomato race 1 (T1) strains: Evidence for antagonism. (Abstr.) Phytopathology 84:1094.

7. Fett, W. F., Dunn, M. F., Maher, G. T., and Maleef, B. E. 1987. Bacteriocins and temperate phage of Xanthomonas campestris pv. glycines. Curr. Microbiol. 16:137-144.

8. Figurski, D., and Helinski, D. R. 1979. Replication of an origin-containing derivative of plasmid RK2 dependent on plasmid function provided in trans. Proc. Natl. Acad. Sci. 77:7347-7351.

9. Frey, P., Smith, J. J., Albar, L., Prior, P., Marie, C., Saddler, G. S., Trigalet-Demery, D., and Trigalet, A. 1996. Bacteriocin typing of Burkholderia (Pseudomonas) solanacearum race 1 of the French West Indies and the correlation with genomic variation of the pathogen. Appl. Environ. Microbiol. 62:473-479.

10. Jones, J. B., Bouzar, H., Somodi, G. C., Stall, R. E., Pernezny, K., ElMorsy, G., and Scott, J. W. 1998. Evidence for the preemptive nature of tomato race 3 of Xanthomonas campestris pv. vesicatoria in Florida. Phytopathology 88:33-38.

11. Jones, J. B., Bouzar, H., Stall, R. E., Almira, E. C., Roberts, P. D., Bowen, B. W., Sudberry, J., Strickler, P. M., and Chun, J. 2000. Systematic analysis of Xanthomonads (Xanthomonas spp.) associated with pepper and tomato lesions. Int. J. Syst. Evol. Microbiol. 50:12111219.

12. Jones, J. B., Stall, R. E., and Bouzar, H. 1998. Diversity among Xanthomonas pathogenic on pepper and tomato. Annu. Rev. Phytopathol. 36:41-58.

13. Jones, J. B., Stall, R. E., Scott, J. W., Somodi, C. G., Bouzar, H., and Hodge, N. C. 1995. A third tomato race of Xanthomonas campestris pv. vesicatoria. Plant Dis. 79:395-398.

14. Lakey, J. H., van der Goot, F. G., and Pattus, F. 1994. All in the family: The toxic activity of pore-forming colicins. Toxicology 87:85-108.

15. Liu, T. 1998. Biological control of tomato bacterial spot with a HRPmutant of Xanthomonas campestris pv. vesicatoria. M.S. thesis. University of Florida, Gainesville.

16. Miller, J. H. 1972. Experiments in Molecular Genetics. Cold Spring Harbor Laboratory, Cold Spring Harbor, NY.

17. O'Garro, L. W., and Tudor, S. 1994. Contribution of four races of Xanthomonas campestris pv. vesicatoria to bacterial spot in Barbados. Plant Dis. 78:88-90.

18. Papathanasopoulos, M. A., Krier, F., Revol-Junelles, A.-M., Lefebre, G., Le Caer, J. P., von Holly, A., and Hastings, J. W. 1997. Multiple bacteriocin production by Leuconostoc mesenteroides TA33a and other Leuconostoc/Weissella strains. Curr. Microbiol. 35:331-335.

19. Pohronezny, K., Stall, R. E., Canteros, B. I., Kegley, M., Datnoff, L. E., and Subramanya, R. 1992. Sudden shift in the prevalent race of Xanthomonas campestris pv. vesicatoria in pepper fields in Southern Florida. Plant Dis. 76:118-120.

20. Rougal, M., and Carr, S. R. 1972. Variable ammonia production among smooth and rough strains of Pseudomonas pseudomallei: Resemblance to bacteriocin production. J. Bacteriol. 112:372-380.

21. Sambrook, J., Fritsch, E. F., and Maniatis, T. 1989. Molecular Cloning: A Laboratory Manual. 2nd ed. Cold Spring Harbor Laboratory, Cold Spring Harbor, NY.

22. Stall, R. E., Beaulieu, C., Egel, D., Hodge, N. C., Leite, R. P., Minsavage, G. V., Bouzar, H., Jones, J. B., Alvarez, A. M., and Benedict, A. A. 1994. Two genetically diverse groups of strains are included in Xanthomonas campestris pv. vesicatoria. Int. J. Syst. Bacteriol. 44:4753.

23. Stall, R. E., Loschke, D. C., and Jones, J. B. 1986. Linkage of copper resistance and avirulence loci on a self-transmissible plasmid in Xanthomonas campestris pv. vesicatoria. Phytopathology 76:240243. 
24. Staskawicz, B. J., Dahlbeck, D., Keen, N., and Napoli, C. 1987. Molecular characterization of cloned avirulence genes from race 0 and race 1 of Pseudomonas syringae pv. glycinea. J. Bacteriol. 169:57895794.

25. Tagg, J. R., Dajani, A. S., and Wannamaker, L. W. 1976. Bacteriocins of Gram-positive bacteria. Bacteriol. Rev. 40:722-756.

26. Tagg, J. R., and McGiven. 1971. Assay system for bacteriocins. Appl. Microbiol. 21:943.

27. Tudor, S. M. 1995. An analysis of antagonism in tomato race-three strains of Xanthomonas campestris pv. vesicatoria. M.S. thesis. University of Florida, Gainesville.
28. Vauterin, L., Hoste, B., Kersters, K., and Swings, J. 1995. Reclassification of Xanthomonas. Int. J. Syst. Bacteriol. 45:472-489.

29. Vidaver, A. K. 1976. Prospects for control of phytopathogenic bacteria by bacteriophages and bacteriocins. Annu. Rev. Phytopathol. 14:451-465.

30. Vidaver, A. K. 1983. Bacteriocins: The lure and the reality. Plant Dis. 67:471-475

31. Whalen, M. C., Wang, J. F., Carland, F. M., Heiskell, M. E., Dahlbeck, D., Minsavage, G. V., Jones, J. B., Scott, J. W., Stall, R. E., and Staskawicz, B. J. 1993. Avirulence gene avrRxv from Xanthomonas campestris pv. vesicatoria specifies resistance on tomato line Hawaii 7998. Mol. Plant-Microbe Interact. 6:616-627. 